\title{
Pengaruh Kepemimpinan Kepala Sekolah terhadap Motivasi Kerja Guru di MA Swasta Nururrodhiyah Kota Jambi
}

\author{
Jamaluddin $^{1 *}$, Dian Nisa Istofa ${ }^{2}$, \& Bety Suremi ${ }^{3}$ \\ Universitas Islam Negeri Sulthan Thaha Saifuddin, Jambi \\ *corresponding author: khairunas@uinjambi.ac.id
}

\begin{abstract}
:
This research aims to find out the magnitude of the influence of the principal's leadership on the motivation of teacher work in the Private MA Nururrodhiyah Kota Jambi. This research is a quantitative study using correlational research design, while data analysis techniques use normality and product moment correlation tests. The results of this study found that the sample of principals in 20 teachers who were sampled obtained an average score of 70, a median of 72,625, a mode of 72 with a standard deviation of 13,265. While the results of teacher work motivation from the data obtained an average score of 77.8, median of 77.5, mode of 74.5, and standard deviation of 27.72. The product moment correlation test rxy $=0.976$ is greater than rtabel so it is known that at the significance level of $5 \%=0.444$ and at the significance level of $1 \%=0.561$ then Ho was rejected and Ha accepted.
\end{abstract}

KEYWORDS: Principal leadership; teacher work motivation.

\begin{abstract}
ABSTRAK:
Penelitian ini bertujuan untuk mengetahui besarnya pengaruh kepemimpinan kepala sekolah terhadap motivasi kerja guru di MA Swasta Nururrodhiyah Kota Jambi. Penelitian ini merupakan penelitian kuantitatif dengan menggunakan desain penelitian korelasional, sedangkan teknik analisis data menggunakan uji normalitas dan korelasi product moment. Hasil penelitian ini menemukan bahwa sample kepala sekolah pada 20 guru yang dijadikan sampel didapat hasil nilai rata-rata sebesar 70, median sebesar 72.625, modus sebesar 72 dengan standar deviasi sebesar 13.265. Sedangkan hasil dari motivasi kerja guru dari data tersebut didapat nilai rata-ratanya sebesar 77.8 , median sebesar 77.5, modus sebesar 74.5, dan standar deviasi sebesar 27.72. Pengujian korelasi product moment $r_{x y}=0.976$ lebih besar dari pada $r_{\text {tabel }}$ sehingga diketahui bahwa pada taraf signifikansi $5 \%=0.444$ dan pada taraf signifikansi $1 \%=0.561$ maka Ho ditolak dan Ha diterima.
\end{abstract}

KATA KUNCI: Kepemimpinan kepala sekolah; motivasi kerja guru.

Copyright (C) Published by Program Studi Manajemen Pendidikan Islam Fakultas Tarbiyah dan Keguruan

Universitas Islam Negeri Sulthan Thaha Saifuddin jambi Mendalo Darat, Muaro Jambi, 36361, Indonesia 


\section{PENDAHULUAN}

Kepemimpinan pada dasarnya adalah suatu proses sosial yang diadakan agar dapat dijadikan sebuah alat untuk menciptakan kebaikan bersama dalam suatu lingkup tertentu dalam masyarakat. Setiap kelompok organisasi yang bersifat sosial maupun politik selalu bergelut dengan kepemimpinan meliputi sekumpulan dari serangkaian kemampuan dan sifat-sifat kepribadian. Kepemimpinan menjadi bagian dari kewibawaan untuk dijadikan sebagai sarana dalam rangka menyakinkan yang dipimpinnya agar mau dan dapat melaksanakan tugas-tugas yang dibebankan kepadanya dengan rela, penuh semangat, ada kembiraan batin, serta merasa tidak terpaksa (Purwanto, 2003).

Pemimpin berkaitan juga dengan penggerakan (motivating) yang dapat diartikan sebagai upaya pimpinan untuk menggerakkan (memotivasi) seseorang atau kelompok orang yang dipimpin dengan menumbuhkan dorongan atau motif dalam diri orang-orang yang dipimpin untuk melakukan tugas atau kegiatan yang diberikan kepadanya sesuai dengan rencana dalam rangka mencapai tujuan organisasi (Sudjana, 2004). Seorang kepala sekolah harus mampu meningkatkan kinerja para guru atau bawahannya dengan cara memberikan motivasi yang mampu memengaruhi kinerja seorang guru. Pemimpin sekolah harus mampu memberikan pengaruh-pengaruh yang dapat menyebabkan guru tergerak untuk melaksanakan tugasnya secara efektif sehingga kinerja guru akan lebih baik. Motivasi merupakan suatu kekuatan potensial yang ada pada diri seseorang, yang dapat dikembangkan oleh diri sendiri ataupun dikembangkan dengan oleh sejumlah kekuatan luar. Dalam psikologi motivasi diartikan sebagai segala sesuatu yang menjadi pendorong timbulnya suatu tingkah laku (Sabri, 1996).

Sebagai pemimpin yang mempunyai pengaruh, ia berusaha memberikan nasihat, saran dan jika perlu perintahnya diikuti oleh para guru. Dengan demikian ia dapat mengadakan perubahan-perubahan dalam pola pikir dan sikap serta tingkah laku para guru yang dipimpinya. Dengan kelebihan yang dimilikinya yaitu kelebihan pengetahuan dan pengalaman, ia membantu guru-guru berkembang menjadi guru yang profesional. 
Dalam melaksanakan fungsi kepemimpinannya, kepala sekolah harus melakukan pengelolaan dan pembinaan sekolah melalui kegiatan administrasi, manajemen dan kepemimpinan yang sangat tergantung pada kemampuannya. Oleh karena itu, segala penyelanggaraan pendidikan akan mengarah kepada usaha meningkatkan mutu pendidikan yang sangat dipengaruhi oleh guru dalam melaksanakan tugasnya secara operasional. Melihat pentingnya salah satu fungsi kepemimpinan kepala sekolah sebagai supervisor dalam pengawasan kinerja guru, maka usaha untuk meningkatkan kinerja yang lebih tinggi bukanlah merupakan pekerjaan yang mudah bagi kepala sekolah. Karena kegiatan berlangsung sebagai proses yang tidak muncul dengan sendirinya.

Pada kenyataannya banyak kepala sekolah yang sudah berupaya secara maksimal untuk meningkatkan kualitas pendidikan, salah satunya caranya memotivasi para guru-guru agar memiliki kinerja lebih baik hasilnya masih jauh dari harapan. Hal ini terjadi timbul dari perilaku sebagian guru, seperti guru kurang disiplin dalam mengerjakan tanggung jawabnya, konsisten waktu yang rendah, tingkat kehadiran guru menurun, sistem atau cara mengajar guru sangat monoton. Oleh karena itu diperlukan upaya lebih lanjut dan lebih insentif, agar pendidikan sekolah tetap dapat mencapai tujuan yang sebenarnya, maka perlu adanya motivasi kerja dalam mengelola kepemimpinan kepala sekolah terhadap kerja guru.

Kepala Sekolah dalam organisasi sekolah merupakan pimpinan yang bertanggungjawab atas kelangsungan organisasi tersebut. Usaha pengelolaan dan pembinaan sekolah melalui kegiatan administrasi, manajemen dan kepemimpinan tergantung pada kemampuan kepala sekolah. Sehubungan dengan itu maka dapat dikatakan bahwa kepala sekolah selaku administrator berfungsi untuk merencanakan, mengorganisasikan, mengarahkan, mengkoordinasikan dan mengawasi seluruh kegiatan pendidikan yang diselengggarakan di suatu sekolah. Kepala sekolah sebagai manajer pendidikan berfungsi mewujudkan pendayagunaan setiap personal secara tepat, agar mampu melaksanakan tugas-tugasnya secara maksimal untuk memperoleh hasil yang sebesar-besarnya, pada segi kuantitas maupun kualitas dalam proses mengajar belajar di sekolah (Hadari, 1985). Motivasi pada dasarnya dapat bersumber dari diri sesorang atau yang sering dikenal sebagai motivasi internal dan dapat pula bersumber dari luar diri seseorang atau disebut juga motivasi 
eksternal. Motivasi merupakan salah satu alat atasan agar bawahan mau bekerja cerdas sesuai yang diharapkan. Manajer dalam hal ini adalah kepala sekolah dapatmemotivasi pegawainya dengan cara yang berbeda-beda sesuai dengan polanya masing-masing yang menonjol (Sadiman, 1992). Motivasi yang baik dari atasan atau kepala sekolah memegang peranan yang sangat penting untuk memberikan dorongan kepada guru, sehingga dengan adanya motivasi yang baik dari Kepala Sekolah maka kinerja gurudiharapkan akan meningkat menjadi lebih baik. Mengingat cukup beratnya tugas-tugas yang harus dilakukan oleh seorang guru, maka sudah sepantasnya guru mendapatkan banyak hal yang dapat membangkitkan semangat dalam bekerja. Hal ini penting, karena seorang guru akan menghasilkan kinerja yang baik jika memiliki kompetensi yang baik serta memiliki motivasi kerja yang cukup.

Pembentukan kinerja guru yang efektif merupakan hasil kombinasi dari banyak faktor, seperti komitmen, pertumbuhan pribadi, lingkungan sekolah, budaya yang berlaku, inovasi guru dan lain-lain. Semua faktorfaktor memiliki hubungan langsung atau tidak langsung dengan tindakan yang dilakukan oleh kepala sekolah. Kepala sekolah sebagai pimpinan tertinggi yang sangat berpengaruh dan menentukan kemajuan sekolah harus memiliki kemampuan administrasi, memiliki komitmen tinggi, dan luwes dalam melaksanakan tugasnya. Kepemimpinan kepala sekolah yang baik harus dapat mengupayakan peningkatan kinerja guru melalui program pembinaan kemampuan tenaga kependidikan. Oleh karena itu kepala sekolah harus mempunyai kepribadian atau sifat-sifat dan kemampuan serta keterampilanketerampilan untuk memimpin sebuah lembaga pendidikan. Dalam perannya sebagai seorang pemimpin, kepala sekolah harus dapat memperhatikan kebutuhan dan kemampuan yang dimiliki oleh guru dan berusaha untuk meningkatkan kemampuan dan kinerja guru (Nasrun, 2016).

\section{METODE}

Penelitian ini menggunakan metode kuantitatif. Teknik pengambilan sampel yang digunakan dalam penelitian ini adalah proportionate stratified random sampling, merupakan teknik yang digunakan bila populasi mempunyai anggota / unsur yang tidak homogen dan berstrata secara proporsional (Sugiyono, 2010), dengan jumlah keseluruhan sampel sebanyak 20 orang. Adapun hipotesis yang peneliti ajukan dalam penelitian ini berkaitan dengan 
teori yaitu diduga kurangnya motivasi yang diterima oleh guru sehingga berdampak pada kinerja guru di Madrasah Aliyah Swasta Nururrodhiyah Kota Jambi. Hipotesis Tindakan berupa kepemimpinan kepala sekolah terhadap motivasi kerja guru, maka dapat dirancang kerangka berfikir kepemimpinan kepala sekolah sebagai variabel independen dan motivasi kerja guru sebagai variabel dependen.

\section{HASIL PENELITIAN DAN PEMBAHASAN}

Motivasi adalah mempersoalkan bagaimana caranya mengarahkan daya potensi bawahan agar mau bekerja secara produktif serta berhasil mencapai dan mewujudkan tujuan yang telah ditentukan. Menurut Hasibuan (2001) motivasi berasal dari kata dasar motif, yang mempunyai arti suatu perangsang, keinginan dan daya penggerak kemauan bekerja seseorang. Motivasi adalah pemberian daya penggerak yang menciptakan kegairahan kerja seseorang agar mau bekerjasama dengan efektif dan terintegrasi dengan segala daya upaya untuk mencapai kepuasan. Robbins (2001) motivasi adalah kesediaan untuk mengeluarkan tingkat upaya yang tinggi untuk tujuan organisasi yang dikondisikan oleh kemampuan upaya itu dalam memenuhi beberapa kebutuhan individual. Kebutuhan terjadi apabila tidak ada keseimbangan antara apa yang dimiliki dan apa yang diharapkan (Nasrun, 2016).

Kinerja adalah performance atau unjuk kerja. Kinerja dapat pula diartikan prestasi kerja atau pelaksanaan kerja atau hasil unjuk kerja. Minner (1992) mengemukakan kinerja merupakan kesesuaian perilaku yang diharapkan oleh organisasi. Ahli lain yaitu Griffin (1997) menyatakan bahwa kinerja adalah totalitas perilaku yang berhubungan dengan pekerjaan yang diharapkan organisasi untuk ditampilkan. Setiap guru berusaha untuk melaksanakan tugasnya dengan baik untuk menghasilkan hasil yang memuaskan guna tercapainya tujuan sebuah organisasi atau kelompok dalam suatu unit kerja. Jadi, kinerja guru merupakan hasil kerja dalam mencapai persyaratan-persyaratan pekerjaan. Persyaratan tersebut biasanya telah ditetapkan dalam suatu organisasi, termasuk dalam lingkungan sekolah. Standar kinerja perlu dirumuskan untuk dijadikan acuan dalam mengadakan penilaian, yaitu dengan membandingkan apa yang dicapai dengan apa yang diharapkan. Standar kinerja dapat dijadikan patokan dalam mengadakan 
berbagai pertanggungjawaban terhadap apa yang telah dilaksanakan (Nasrun, 2016).

Hasil analisis pada instrumen kepemimpinan kepala sekolah dan motivasi kerja guru menunjukkan semua butir pernyataan yang telah diuji kepada responden (guru) dinyatakan valid dan reliabel. Sesuai dengan teori yang dikemukakan oleh Sugiyono menyebutkan instrumen yang valid dan reliabel merupakan syarat mutlak untuk mendapatkan hasil yang valid dan reliabel. Kepemimpinan kepala sekolah yang didapat dari instrumen observasi yang berupa pernyataan berbentuk angket sampel sebanyak 20 orang dengan butir pertanyaan dan hasil uji validitas yang dilakukan menunjukan terdapat 17 pernyataan yang valid dan 3 pernyataan yang tidak valid, dengan nilai maksimumnya adalah 84 dan minimumnya adalah 6o. Dari data tersebut didapat nilai rata-ratanya sebesar 70 , mediannya sebesar 72.625 , modus sebesar 72 dengan standar deviasi sebesar 13.265 .

Motivasi kerja guru yang didapat dari instrument observasi yang berupa pernyataan yang berbentuk angket sampel sebanyak 20 orang dengan butir pernyataan dan hasil uji validitas yang dilakukan menunjukan terdapat 18 pernyataan yang valid dan 1 pernyataan yang tidak valid, dengan nilai maksimum sebesar 86 dan nilai minimum sebesar 54. Dari data tersebut didapat nilai rata-ratanya sebesar 77.8, median sebesar 77.5, modus sebesar 74.5, dan standar deviasi sebesar 27.72 .

Berdasarkan perhitungan yang telah dilakukan oleh peneliti didapatkan hasil yaitu pengaruh kepemimpinan kepala sekolah terhadap motivasi kerja guru menunjukkan hasil pengujian korelasi product moment terdapat $\mathrm{r}_{\mathrm{xy}}$ yang besarnya 0.976 lebih besar dari pada $\mathrm{r}_{\text {tabel }}$ pada taraf signifikansi 5\% (o.444) dan 1\% (0.561), maka Ho ditolak dan Ha diterima. Hal ini menunjukkan adanya pengaruh yang signifikan antara kepemimpinan kepala sekolah terhadap motivasi kerja guru.

Hal ini sejalan dengan pendapat yang dikemukakan oleh beberapa penelitian terdahulu, Syahrizal Adli (2010) dalam penelitiannya menunjukkan kepemimpinan kepala sekolah dengan sampel sebanyak 25 nilai rata-rata sebesar 101.85, nilai median sebesar 103.2, nilai modus sebesar 104.3, dan standar deviasi sebesar 7.68 , sedangkan motivasi kerja guru menunjukkan nilai rata-rata sebesar 40.24, nilai median sebesar 40.56, nilai modus sebesar 40.3 
dan standar deviasi sebesar 4.14. Korelasi product moment yang menyatakan bahwa terdapat $r_{\mathrm{xy}} 0.801$ lebih besar dari pada $\mathrm{r}_{\text {tabel }}$ pada taraf signifikan $5 \%$ (o.396) dan 1\% (0.505) maka Ho ditolak dan Ha diterima sehingga terdapat signifikansi antara kepemimpinan kepala sekolah terhadap motivasi kerja guru. Turmiyati (2016) juga memperoleh hasil penelitian mengenai pengaruh kepemimpinan kepala sekolah terhadap motivasi kerja guru di MTs Al-Hikmah Kedaton Bandar Lampung, yang menyatakan bahwa gaya kepemimpinan demokratis kepala madrasah (X) dapat diketahui mean sebesar 106.35 dan standar deviasi sebesar 10.748. Selain data tersebut dapat diketahui pula nilai maksmum sebesar 120 dan nilai minimum sebesar 90. Sedangkan motivasi kerja guru dapat diketahui nilai mean sebesar 4.16 dan standar deviasi sebesar 1.537. Selain data tersbut dapat diketahui pula nilai maksimum sebesar 120 dan nilai minimum sebesar 78 dengan nilai korelasi antara X dan Y sebesar 64.8\%. Berdasarkan hasil analisis peneliti menyimpulkan terdapat pengaruh antara gaya kepemimpinan kepala sekolah dengan motivasi kerja guru.

Hasil penelitian yang dilakukan Aeni Rahmi (2017), tentang hubungan kepala sekolah dengan kinerja guru diperoleh uji signifikansi jika Ho diterima, hal ini berarti kostantan persamaan regresi tidak signifikan. Jika Ho ditolak berarti koefisien regresi bersifat signifikan. Dari hasil perhitungan diperoleh $t_{\text {hitung }}=79.44$ sementara $t_{\text {tabel }}=3.18$ untuk taraf signifinkansi $5 \%$. Karena $t_{\text {hitung }}$ lebih besar dari $t_{\text {tabel }}$ maka dapat disimpulkan bahwa Ho ditolak dan $\mathrm{Ha}$ diterima, sehingga terdapat pengaruh yang signifikan antara kepemimpinan kepala sekolah terhadap motivasi kerja tenaga administrasi.

Temuan Anita Juniarti (2010) di MAN Malang II Batu tentang pengaruh gaya kepemimpinan kepala sekolah terhadap motivasi mengajar guru menunjukkan terdapat pengaruh yang positif dan signifikan antara gaya kepemimpinan kepala sekolah terhadap motivasi kerja guru. Adapun besar pengaruh gaya kepemimpinan kepala sekolah terhadap motivasi kerja guru adalah sebesar $72.8 \%$, sedangkan sisanya yaitu $27.7 \%$ dipengaruhi oleh faktorfaktor lain. Hal ini terbukti dari 54 responden yang ada, sebanyak 45 orang (83.33) menyatakan bahwa gaya kepemimpinan kepala sekolah demokratis, sebanyak 9 orang (16.6\%) menyatakan bahwa kepemimpinan kepala sekolahkadang-kadang demokratis dan (o\%) menyatakan bahwa gaya kepemimpinan kepala sekolah tidak demokratis. 
Hasil penelitian ini juga menunjukkan terdapat pengaruh yang positif dan siginifikan. Karena itu baik tidaknya kepepemimpinan kepala sekolah berpengaruh terhadap tinggi rendahnya motivasi kerja guru dalam menjalankan tugasnya dengan pengaruh yang kuat atau tinggi. Berdasarkan penelitian di atas dapat diketahui bahwa semakin bagus kepemimpinan kepala sekolah maka akan mempengaruhi motivasi kerja guru yang ada di suatu sekolah dan akan berdampak pula pada tercapainya tujuan atau visi misi sekolah tersebut. Korelasi ini bernilai positif, yang berarti kenaikan pada indeks kepemimpinan kepala sekolah akan diikuti oleh kenaikan pada kinerja guru. Dari teori dan temuan hasil penelitian terdahulu dan dikaitkan dengan hasil penelitian yang diperoleh, jelas bahwa untuk meningkatkan kinerja guru dapat dilakukan dengan meningkatkan kepemimpinan kepala sekolah.

\section{SIMPULAN}

Hasil penelitian menunjukkan besarnya taraf signifikansi $5 \%=0.444$ dan pada taraf signifikansi $1 \%=0.561$ sehingga hasil pengujian korelasi product moment terdapat $\mathrm{r}_{\mathrm{xy}}$ yang besarnya 0.976 lebih besar dari $\mathrm{r}_{\text {tabel }}$ maka Ho ditolak dan Ha diterima yang artinya terdapat pengaruh kepemimpinan kepala sekolah terhadap motivasi kerja guru di Madrasah Aliyah Swasta Nururrodhiyah Kota Jambi bahwa antara keduanya terdapat hubungan yang sangat tinggi.

\section{REFERENSI}

Fatah, N. (1996). Landasan Manajemen Pendidikan. Bandung: Remaja Rosdakarya.

Fremont, \& Rosenzweig. (2002). Organisasi dan Manajemen. Jakarta: Bumi Aksara.

Irman, \& Rohim. (2004). Membawa Diri Kepuncak Prestasi. Jember: Seyma Media.

Ishak, \& Hendri. (2003). Manajemen Motivasi. Jakarta: PT. Gramedia Widiasarana.

Kartono, \& Kartini. (2005). Kepemimpinan: Apakah Kepemimpinan Abnormal itu? Jakarta: PT Raja Grafindo Persada.

Karwati, \& Priansa. (2016). Kinerja dan Profesionalisme Kepala Sekolah Membangun Sekolah yang Bermutu. Bandung: Alfabeta. 
Nasrun. (2016). "Pengaruh Kepemimpinan Kepala Sekolah Terhadap Motivasi Kerja dan Kinerja Guru.” Ilmu Pendidikan, 1(2): 63-70.

Pianda. (2018). Kinerja Guru. Jawa Barat: CV Jejak.

Sudaryono. (2018). Metodologi Penelitian. Depok: Rajawali Pers.

Sugiyono. (2010). Metode Penelitian Pendidikan: Pendekatan Kuantitatif, Kualitatif dan RED. Bandung: Alfabeta.

Sukmadinata, Nana Syaodih. (2016). Metode Penelitian Pendidikan. Bandung: PT Remaja Rosdakarya.

Tzu, \& Cleary. (2002). Seni Perang. Jakarta: Erlangga.

Wahyosumidjo. (2005). Kepemimpinan Kepala Sekolah. Jakarta: PT. RajaGrafindo. 